Linguistik Terapan 15 (1) (2018): 40-49

Jurnal Linguistik Terapan Pascasarjana

Available online http://jurnal.unimed.ac.id/2018/index.php/JLT-

Unimed

\title{
MANDAILING LANGUAGE MAINTENANCE IN KELURAHAN SUDIREJO II MEDAN
}

\author{
Nisma Zuri \\ Sumarsih \\ Edy Setia
}

Diterima Januari 2018; Disetujui Pebruari 2018; Dipublikasikan April 2018

\begin{abstract}
This study deals with Language Maintenance in Kelurahan Sudirejo II Medan. The objectives of the study are (1) to describe out the factors affecting Mandailing Languagein Kelurahan Sudirejo II Medan (2) to elaborate how Mandailingnese maintain the Mandailing Languagein Kelurahan Sudirejo II Medan, and (3) to reason for the manners or way by which they maintain Mandailing Languagein Kelurahan Sudirejo II Medan. The method of this study was descriptive qualitative research. The participants were twenty Mandailing people who live in Kelurahan Sudirejo II Medan. The data were taken from questionnaire and interview as instrument. Questionnaire was applied to collect the data about the factors affecting the Mandailing Language maintenane and strategies in maintaining ML. While the interview was applied to get data about the reason of Mandailing people maintain Mandailing Language. The data were analyzed by using Miles and Huberman matrix (1994). This research found the following results (1) There are seven factors affecting Mandailing Languagemaintenance in Kelurahan Sudirejo II Medan such as: Use of language in family (intermarriage and intermarriage), visiting homeland, use of the language in neighborhood domain, ethno linguistic vitality, living together in an area, use of the language in religion and practice of traditional ceremony. (2) to maintain Mandailing Language, the Mandailing people in Kelurahan Sudirejo II Medan conducted strategies like: Family language policy, using Mandailing Languagein daily life, using Mandailing Languagein social meeting or religious, using Mandailing Languagein cultural activity. (3) the reasons why the Mandailing people maintain the language are: they were proud being Mandailing people and speak Mandailing language and Mandailing Languageshows their identity as Mandailing people.
\end{abstract}

Keywords: Language maintenance and Mandailing.

How to Cite: Zuri, Nisma (2018).

Mandailing Language Maintenance in Kelurahan Sudirejo II Medan. Jurnal Linguistik Terapan Pascasarjana Unimed, 15 (1): 40-49

ISSN 2407-7410 


\section{INTRODUCTION}

Language is obviously a vitall tool for communication. It is not only as a means of communicating thoughts and ideas, but also it is use for creating friendship, cultural ties, economic relationship, etc. The existence of language for human life is very important. Without a language, the society cannot be form and there will be not community. Nowadays, language shift potentially happen in vernaculars in Indonesia. Gunarwan (2004) found that Lampung language is shifted because of Indonesian language pressure. Siregar (1998) also found that language shift happen in the young generation bilingual society in Medan. The data show that the language shift happens in Indonesia continually.

Weinreich (1968) defines that language shift is often used to refer to change at a community level and the terms language loss or non-acquisition of language are used in reference to an individual's declining or use of a group's original language with concurrent increased or dominant use of another more widely used language. Then, Pauwels (2005) states that language maintenance is generally applied to individuals or community of speakers continuing to use their language in a situation of language contact, where there is competition from one or more languages to be the sole language used in particular domains or situations. It means that maintaining the language is important. It is supported by Holmes (2001) said tht where the language is considered as an important symbol of minority group's identity, it is likely to be maintained longer. Moreover Schiffman (1995) warned that if language is not maintained, there can be several results. One is language death, speakers become bilingual, younger speakers become dominant in another language, and the language is said to die.

Thus, the researcher intends to know the factors affect the maintenance of ML in Kelurahan Sudirejo II Medan; the way of Mandailingnese maintain their language and the reasons of Mandailingnese maintain their language as the way the do.

Language Maintenance

Language maintenance refers to the situation where speech community, under circumtance that would seems to favor language shift, hold on to its language (Weinrich, 1953: 68). Its also refers to if the minority language is retaine by its traditional community without the interventionof language planning activiies (Hyltenstam \& Stroud, 1996).

Gibbon and Ramirez (2004) agree that family is the first steps to do the action. Within inside a certain group of language use, the interaction among the member of the group will be important in maintaining their own language. While Crystal (2003) states that language maintenance should be done in order to (a) creating cultural diversity, (b) keep ethnic identity), (c) enable socio adaptability, (d) increasing security for the children psychologically, and (e) increase the sensitivity of linguistic.

\section{The Factors Affecting Language Maintenance}

Language maintenance mostly happen when certain language is considered as minority language. A minority language is a language spoken by a minority of the population of a territory. In 
doing such thing, there must be some reasons behind it. There are some factors that push us to keep the language.

As Fishman in Holmes (2008:21) identifies there are five domains of language use that affect the maintenance of a language such as (1) family domain, (2) friendship domain (neighborhood domain), (3) religion domain, (4) education domain and (5) employment (workplace) domain. Based on the explanation above, it can be concluded that there are the factors that affect language maintenance; (1) Living together and see each other frequently. In other words, it is refers to living in an area dominated by Mandailingnese; (2) Visiting homeland regularly or frequently; (3)Ethno linguistics vitality; (4) Use of the language in family domain (intramarriage and intermarriage); (5); (6) Use of the language in neighborhood domain; (7) Use of the language in workplace domain; (8) Use of the language in education domain; (9) Use of the language in religion domain; and (9) Practice of traditional ceremony.

\section{Strategy for Language Maintenance}

Language is an identity, because of that all languages are hopefully to be maintained. This study about vernacular, it is ML maintenance. As another language, ML is used as a means of communication of local language especially in Kelurahan Sudirejo II Medan.

According to Kayam (2014) states that family language policy is a strategy to maintain the heritage language. Family language policy is a highly important factor in transmitting Mandailing Language, hence maintaining it, as it keeps it functional. That is, it continues to be used in daily life. Thus, the children's use of ML at home helps them to maintain it as a medium for communication in the family. In addition, Schawartz (2010) states that in family language family are about how languages are managed learned and practice at home. As Fishman (1991) said that through watching such as a variety shows, movies, talks shows, children's programming which show by heritage language are strategy for maintaining the heritage language. Fishman (1966) point out that the various institutions, such as language schools, social meeting or religious congregation, social clubs and ethnic restaurant and shops, serve to maintain or minority language within and ethno linguistic community. It means that, by doing these strategies it can help to maintain heritage language, moreover for ML maintenance.

Based on the explanation above, many strategies which can be done in maintaining the language, they are; (1) Family language policy, (2) watching vernacular satellite channel, (3) mass media in vernacular Satellite channel, (4) listening to the radio in vernacular program, (5) using ML in their daily life frequently, (6) using ML in religious congregations like in Perwiritan, (7) using ML in cultural activity like in wedding ceremony and (8) National Seminar about vernacular language by presenting linguist.

\section{The Reasons of Language Maintenance}


According to Crystal (2003) language maintenance should be done in order to (a) create cultural diversity, (b) keep ethnic identity), (c) enable socio adaptability, (d) increasing security for the children psychologically, and (e) increase the sensitivity of linguistic. The five terms are related each other, for example when certain language is maintained, of course the identity of language users also maintained and automatically the language will form the cultural diversity.

The maintenance of vernacular language is very important, because language shows the ethnic identity. As Holmes (2001: 158) stated that where language is considered as important symbol of a minority group's identity, the language is likely to be maintained longer. Meanwhile, Thomas (2004: 158) stated that how the language users talk; along with other kinds of social code such how the language users dress or how the language users behave, an important way of displaying who you are, in other words, of indicating your social identity.

\section{RESEARCH METHOD}

The research was conducted by using qualitative descriptive design by using case study approach. The data of this research are the utterances of Mandailing people that contain of language maintenance which found on Kelurahan Sudirejo II Medan. The source of data were 20 Mandailing people. They were selected based on the characteristic as follow: (1)The Mandailing people were born, grown up, lived in Kelurahan Sudirejo II Medan and rare or never leave their village; (2) Multilingual (can speak mandailing language, and bahasa Indonesia); (3) The ranges of age (15-50 years old); (4)The speakers come from different background of profession and; (5)The speakers must be in good health. The technique of data collection was questionnaire and in-depth interview to get more result and reason of language maintenance. The data were the answer of questionnaire from the sample and transcript of the interview and field notes during the interview. In analyzing the data, the researcher use interactive model of Miles, Huberman and Saldana (2014). Miles, Huberman and Saldana elaborate several steps of analyzing data, they are; (1) data collection, (2) data condensation, (3) data display, (4) data verification/ conclusion.

\section{FINDINGS AND DISCUSSION}

Data were analyzed based on Miles, Huberman and Saldana proposed steps, namely data condensation involves the process selecting, focusing, simplifying, abstracting and transforming the data appearing in written up field note or transcriptions.

\section{Data Condensation}

Data condensation consists of the process of selecting, focusing, abstracting, simplifying and transforming. It is aimed at the procession the raw data that appear in the written-up field notes in order to be analyzed. The five steps of the process of data condensation are : (1) Selecting by separate the questionnaire and interview based on the factors of language maintenance; (2) Simplifying to 
means make the data simpler or easier to understand; (3) Abstracting means to consider the data theoretically or separately; and (4)Transforming means to make a through or dramatic change in the form and appearance.

\section{Data Display}

In data display, the data were organized. Below is the example of data analysis.

\section{Factors Affecting ML Maintenance}

After collecting the data, the writer found that there wereseven factors that affect the Mandailing people in maintaining ML in Kelurahan Sudirejo II Medan, they are (1) language in family (Intramarriage-intermarriage), (2) visiting homeland, (3) use of the language in neihgborhood domain, (4) ethno lingustic vitality, (5) living together in an area, (6) use of the language in religion, (7) practice of traditional ceremony. The more dominant factor and have big role in maintaining ML are ethno linguistics vitality and living together in an area.Use of the language in workplace domain, use of the language in education domain are not found in this study, as it is shown by graphic 1 below;

Graphic 4.1 Factors Affecting ML Maintenance

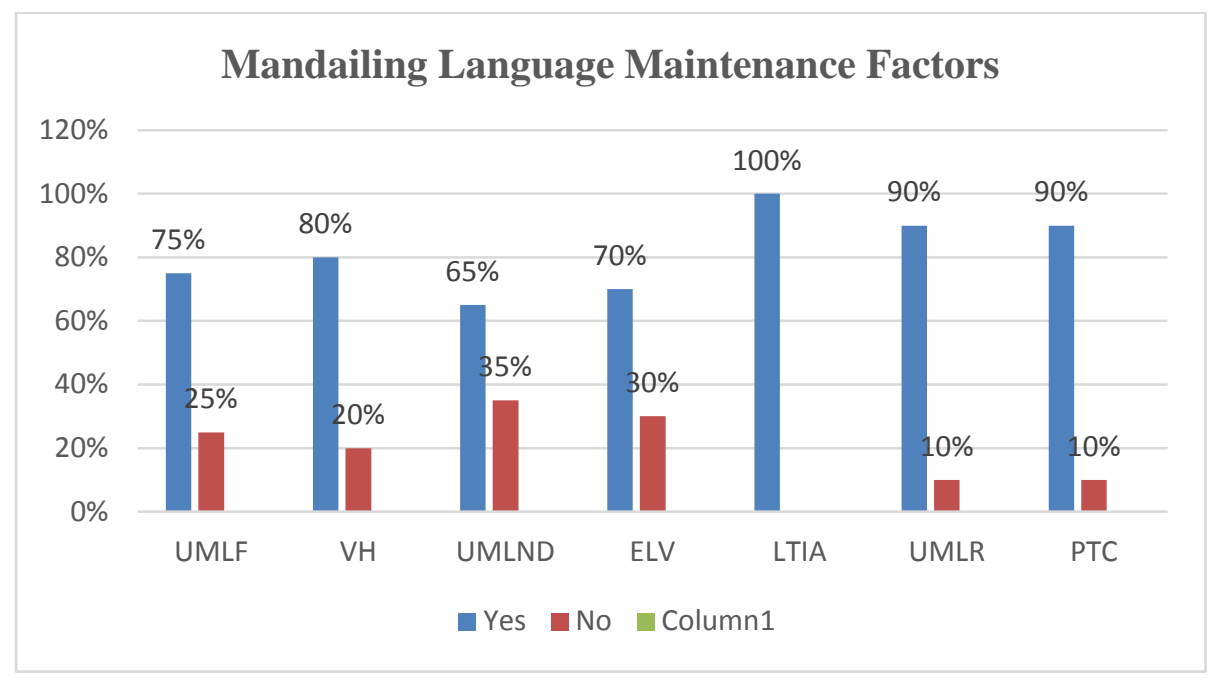

Note:

UMLF : Using ML in Family

VH : Visiting Homeland

UMLND : Using ML in Neigborhood Domain

ELV : Ethno Linguistic Vitality

LTIA : Living Together in an Are

UMLR : Using ML in Religion

PTC : Practice of Traditional Ceremony

\section{A. Use of the Language in Family (Intramarriage-intermarriage)}

In Kelurahan Sudirejo II Medan some of participants who come from intramarriage speak ML at home and some of them intramarriage and intermarriage do not speak Mandailing at home, as shown in table 1 below;

Tabel 4.4 Language use of Mandailing Speaker in Family Domain (Intramarriage-intErmarriage)

No. Factors of Language Maintenance Perquency 
Using language in Family

75

Visiting Homeland 16

80

Using in Neighborhood domain $\quad 13 \quad 65$

Religion $\quad 14 \quad 70$

Ethno Linguistic Vitality $\quad 20 \quad 100$

Living Togather in an Area $\quad 18 \quad 90$

Practice of Traditional Ceremony $\quad 18 \quad 90$

$\begin{array}{lll}\text { Total } & 114 & 100\end{array}$

From the table above, there are $75 \%$ participants who speak ML at home and they are intramarriage family, 3 participants from intramarriage do not speak ML at home and 2 participants from intermarriage do not speak ML at home. As found in Kelurahan Sudirejo II Medan in the following conversation between Mother and child.

A : Madung dipamasak ko ikan i nak? Have you cooked the fish?

B : Olo umak, kehe ma au on. Yes mom I will go

\section{B. Homeland Visits}

Visiting homeland regularly is one factor in maintaining a language. They go to see their homeland, do language contact with the people at homeland. Thus factor affected in increasing the ability of mandailing speakers in speaking ML. As participan number 2 said that:

Alhamdulillah setiap lebaran kami masih diberi rezeki untuk pulang kampung. Keluarga dekat masih banyak disana, jadi satu harian itu disempatkan kerumah keluarga. Enak lah kalo uda kumpul cerita yang pastinya pake bahasa Mandailing. (Alhamdulillah, we were still given the provision to return home. Immediate family is still a lot there, so one day at a time to the family home. Its happy if we have gathered tell which must use the Mandaiing Language).

\section{Use of the Language in Neighborhood Domain}

Using the language in neighborhood domain is one factor concerning with the maintenance of ML. As participant number 8 said that;

Ya kalo jumpa sama tetangga suku Mandailing ya jelas pakai bahasa Mandailing la, tapi nggak jarang juga kalo bahasa nya campur dengan bahasa Indonesia. (If I meet with tribe Mandailing neighborhood so obviously I use ML, but not infrequently also I mixed with Indonesian

About 35\% who can speak Indonesian Language do not use ML in neighbor, but they can speak ML.

\section{Use of the Language in Religion Domain}

The use of ML in religion domain is also significant factor which affect ML maintenance.When the researcher asked the participants about using Mandailing and Indonesian Language in religion domain they said tey use Mandailing and Indonesian Language everytime we conduct meeting or wirit.

A: Eda, giliran nise do wirid hari selasa on? Eda, whose turn wirid Tuesday

$\mathrm{B}$ : Di bagas si taing an, ulang ko lupa jam $2 \mathrm{da}$. In the taing home, dont forget at $02.00 \mathrm{pm}$

A: Insha Allah ro do au eda Insha Allah I will come

B: Jadi ma eda. Okay eda.

\section{E. Ethno Linguistics Vitality}


One factor can affect language maintenance is ethno linguistics vitality. The most factor for the maintenance of a threatened language are the attitude of the speakers toward their own language the importance which they attach to it as a major symbol of their identity. Here is the data:

Jelas saya bangga sekali berbicara bahasa Mandailing dan saya tidak malu. Kalo jumpa sesama orang mandailing walaupun bukan kerabat dekat tetapi seperti saudara rasanya. (Obviously I am very proud to speak Mandailing and I am not shy. If I meets fellow Mandailing although not a close relative, but it feels like a brother or sister)

\section{F. Living Together in an Area}

Living in area that dominated by Mandailing people is one of the factors supported the Mandailing people still maintain their language. Mandailing people maintained their language by using the language while they communicate each other, although sometimes the use ML or Indonesian Language. The researcher found the maintenance of ML in Kelurahan Sudirejo II Medan in the following conversation between Mandailing people:

A : Giot tujia do bou on? Where are you going bou?

B : Oo.. get manabusi ubat baen amangborumu! I want to go to buy medicine for your amangboru

\section{G. Practice Traditional Ceremony}

Practice traditional ceremony is one the factor affecting the maintenance of ML. As the statement of the participant number 17 :

Kalau acara adat Mandailing seperti perkawinan lebih sering pakai bahasa Mandailing, ada acara upah-upah tondi misalnya itu memang menggunakan bahasa Mandailing. Kami juga sering pakai Bahasa Mandailing disini. (If Mandailing custom events such as marriage more often use ML, there are events upa-upa tondi it does use ML. We also often use ML here).

\section{Strategies of Language Maintenance}

Not all strategies are found in this study, (1) family language policy, (2) using ML in their daily life frequently, (3) using ML in religious congregations like in Perwiritan, (4) using ML in cultural activity like in wedding ceremony are found in this study.

Table 4.2 The Distribution of Strategies of Language Maintenance

$\begin{array}{llll}\text { No. } & \text { Stretegies of Language Maintenance } & \text { Ferquency } & \text { Percnetage } \\ 1 & \text { Family Language Policy } & 16 & 100 \\ 2 & \text { Using Daily Communication Frequency } & 15 & 75 \\ 3 & \text { Using Language In Relgious Congregesion } & 14 & 70 \\ 4 & \text { Traditional Organization } & 12 & 60 \\ \text { Total } & & 57 & 100\end{array}$

\section{A. Family Language Policy}

Family language policy is strategy in maintaining the heritage language. As participant number 7 said that;

Ayah memang selalu menagajarkan kami bahasa Mandailing, misalnya dengan cara setiap bapak bicara atau pun menyuruh kami ayah selalu memakai bahasa Mandailing. kalau kami menjawab pake bahasa Indonesia pasti ayah menyambungnya dengan bahasa Mandailing sampai kamipun sadar 
harus menjawab beliau dengan bahasa Mandailing juga. (My father always taught ML, for example by every father talking or always told us to use the ML.If we speak Indonesian father definitely connect it with ML until we too aware he must answer with ML as well).

\section{B. Using ML in Daily Communication Frequently}

After the family language policy, it is continue to be used ML in daily communication. This strategy also supported the Mandailing people in maintaining their language. As participant 4 said that;

Ya.... kalo ngomong sehari-hari pake bahasa Indonesia sama Mandailing. jumpa sama orang yang sama suku saya pake bahasa Mandailing, tapi kalo suku lain pake bahasa Indonesia lah karna gk mungkin ngerti orang itu kalau saya pake bahasa Mandailing. (I use Mandailing and Indonesian language daily, if I meets at the sametribes Mandailings I use language,but if another tribe, I useIndonesian because it cannot possibly understand the language that I use Mandailing.)

\section{Using ML in Religious Congregations}

Using vernacular language in Religious is one of strategy that conduct to maintain vernacular language. As participant 7 stated that;

Kalo disini memang ada khusus pengajian semacam arisan juga khusus orang Mandailing. Kami selalu pakai bahasa Mandailing kalo sedang mengadakan pertemuan ataupun diskusi. kalau pakai bahasa Mandailing rasanya lebih nyambung aja. (If here there is a special sort of social gathering recitals are also special Mandailingpeople. We always use the ML that are meeting or discussion. ifwe are using the MLI felt more connected).

\section{Using ML in Traditional Organization}

Traditional organization is very important to promote about culture or ethnic. By estabilishing traditional organization the young generation of ethnic know about culture of that ethnic. As participant number 1 statement;

Kalo misalnya ada acara pernikahan pasti ada lah acara mangupa atau markobar. ya jelas bahasa nya pake bahasa Mandailing. (If there is a wedding ceremony, there was markobar or mangupaevent, obviously use $M L$ )

\section{The Reasons of Maintaining ML}

'Based on the theory there are three reasons of language maintenance, namely (1) proud being Mandailing people, (2) show the identity Mandailing people. In this study, only two reason have found. The reasons of Mandailing people maintain ML is taken from interview with the participants as it shown by table 12 below.

Table 4.3 The Disribution of Reasons of language Maintenance

$\begin{array}{llll}\text { No. } & \text { The Reason of Language Maintenance } & \text { Ferquency } & \text { Percnetage } \\ 1 & \text { Pride } & 20 & 100 \\ 2 & \text { Show as Identity } & 20 & 100 \\ \text { Total } & 40 & 100\end{array}$

\section{A. Proud being Mandailing People}

From the table 4.3 there are 100\% participants of Mandailing people maintain ML because of proud being Mandailing people. They always use ML in everywhere. As participant number 1 stated: 
kalau saya selalu menggunakan bahasa Mandailing setiap kali jumpa sesama suku. Karena saya merasa bangga dengan suku saya sendiri dan karena bahasa Mandailing ini kan memang bahasa saya dari dulu, dari jaman orangtua saya. (I always use the ML ifmeet with other tribesevery time. Because I feel proud of my own tribes and because it's ML is my language of the past, from the time of my parents).

\section{B. Show the Identity as Mandailing People}

The second reason is show the identity. It is occured in Mandailing people, they use ML to show that they are Mandailing tribe. As participant number 12 statement;

Bahasa Mandailing sangat perlu dipertahankan, karena bahasa Mandailing itu kan bahasa daerah kita. itu menunjukkan identitas kita sebagai orang Mandailing. Jika tidak dipertahankan bahasa itu akan mati. (ML so should be maintained,because the language was the ML our vernacular language, it shows our identity as Mandailing. If not maintained that language will death).

\section{CONCLUSIONS}

Based on the analysis, the research is formulated in the following:

1. There are seven factors affecting ML maintenance in Kelurahan Sudirejo II Medan, they are (1) language in family (Intramarriage-intermarriage), (2) visiting homeland, (3) use of the language in neighborhood domain, (4) ethno linguistic vitality, (5) living together in an area, (6) use of the language in religion, (7) practice of traditional ceremony.The more dominant factor and have big role in maintaining ML are ethno linguistics vitality and living together in an area.

2. In maintaining ML, Mandailing people in in Kelurahan Sudirejo II Medanused strategies such as (1) family language policy, (2) using ML in their daily life frequently, (3) using ML in religious congregations like in Perwiritan, (4) using ML in cultural activity like in wedding ceremony are found in this study. The more dominantn strategies that done by Mandailing people in Kelurahan Sudirejo II Medan to maintain ML are family language policy and using ML in their daily life frequently.

3. The Mandailing people do maintain ML because they proud to be Mandailing people and ML shows their identity as Mandailing people.

\section{REFERENCES}

Crystal, D. 2003. Language Death. Cambridge: Cambrige University Press.

Denzin,N.K. \& Lincoln, Y.S. 1994. Handbook of Qualitative Research. Thousand Oaks :Sage Publication.

Dweik, B. and Al-Obaidi, T. 2014. Syriac Language Maintenance among the Assyrians of Iraq. Vol. 2, No.1, pp. 269-182. American Research Institute for Policy Development.

Gibbons, J \&Ramirez, E. 2004.Maintaining a Minority Language: A Case Study of Hispanic Teenagers.Sydney: Multilingual Matters. 
Holmes, J. 2001. An Introduction to Sociolinguistcs. Essex: Pearson Education

Holmes, J. 2008. An Introduction to Sociolinguistics.3th edition. New York: Pearson Education.

Hyltenstam, C. and Stroud, C. 1996. Language Miantenance. In Contact Linguistics, Goebl et al. (Eds), 567-578. Berlin: Walter de Gruyter

Kayam, Orly. 2014. The Second Generation: Heritage Language Maintenance Native English Speakers Living in Israel-Case Study No.3. Journal of Sociological Research, 5(1), 18-23. Doi:10.5296/jsr.v5il.5133.

Siregar, B U, et al. 1998. Pemertahanan Bahasa dan Sikap Bahasa: Kasus Masyarakat Bilingual di Medan. Jakarta: Depdikbud

Weinrich, Uriel. 1968. Language in Contact: Findings and Problems. The Hauge: Moulion. 